\title{
SISTEM PENDUKUNG KEPUTUSAN PREDIKSI JUMLAH PENUMPANG UNTUK EVALUASI KAPASITAS HALTE BUS TRANS JOGJA DENGAN METODE EXPONENTIAL SMOOTHING DAN LEAST SQUARE
}

\author{
Dwi Prasetiyo, Anton Setiawan Honggowibowo, Yuliani Indrianingsih \\ Jurusan Teknik Informatika \\ Sekolah Tinggi Teknologi Adisutjipto Yogyakarta \\ informatika@stta.ac.id
}

\begin{abstract}
The increasing number of passengers Trans Jogja bus stops can result in the existing capacity can not accommodate the number of passengers comfortably. Problems that often arise include delays resulting bus passenger waiting time is longer and there is a buildup of the number of passengers at stops. As a result of these problems, the capacity of passenger stops can be full so that prospective passengers waiting outside the bus stop. Forecasting is one very important element in the decision. In this study using stationary and trend forecasting the data because the data are not significant changes between time and swell in certain periods and a normal in periods others. Time series methods for forecasting the number of passengers on the Trans Jogja stop using exponential smoothing calculation and least square. From these calculations the value sought MAD (Mean Absolute Deviation) or least square error is exponential smoothing and forecasting results with small error. Forecasting will be better if it contains fewer possible errors.
\end{abstract}

Keyword: Number of passengers, Forecasting, Time Series.

\section{Pendahuluan}

Kemudahan transportasi baik darat dan udara menyebabkan Yogyakarta banyak dikunjungi oleh para wisatawan baik domestik maupun mancanegara. Sejak bulan Maret 2008, direalisasikan sistem transportasi baru di Yogyakarta yaitu Trans Jogja. Semakin bertambahnya jumlah penumpang Trans Jogja dapat mengakibatkan kapasitas halte yang ada tidak dapat menampung sejumlah penumpang dengan nyaman. Pada saat bus Trans Jogja beroperasi melayani penumpang terdapat beberapa permasalahan. Permasalahan yang sering muncul antara lain keterlambatan bus yang berakibat waktu tunggu penumpang menjadi lebih lama dan terdapat penumpukan jumlah penumpang di halte. Kedatangan bus belum bisa diprediksi dengan pasti karena belum ada sistem pantau yang dapat memberitahukan kapan bus datang, berapa lama lagi harus menunggu ataupun sudah sampai mana bus tersebut. Akibat dari permasalahan tersebut, kapasitas halte penumpang dapat menjadi penuh sehingga sebagian calon penumpang tersebut menunggu di luar halte dengan berbagai macam karakter yaitu ada yang berdiri mengantri atau duduk di luar halte sambil menunggu giliran. Antrian diluar halte tersebut untuk beberapa area dapat mengganggu pengguna jalan lain sehingga perlu adanya solusi terhadap permasalahan tersebut. Hal ini disebabkan seiring dengan meningkatnya demand terhadap penggunaan halte Trans Jogja. Perlu adanya pertimbangan dari segi ukuran ruang gerak penumpang baik duduk maupun berdiri agar ruang halte tetap dapat menampung sejumlah penumpang dengan nyaman. 
Metode untuk meramalkan jumlah penumpang dapat dilakukan dengan cara statistika. Metode ini harus dapat memberitahukan secara dini kapan suatu halte bus Trans Jogja harus diperbesar ukurannya dan berapa ukuran yang dibutuhkan. Salah satu metode peramalan yang dapat digunakan adalah metode forecasting. Metode-metode tersebut contohnya adalah metode Exponential Smoothing dan Least Square. Apakah metode ini dapat dipakai untuk meramalkan kapan halte Trans Jogja harus diperbesar ukurannya sehingga membantu dalam pengambilan keputusan.

\section{Landasan Teori}

\subsubsection{Forecasting}

Forecasting (peramalan) adalah salah satu unsur yang sangat penting dalam pengambilan keputusan. Peramalan pada dasarnya merupakan suatu taksiran, namun dengan menggunakan teknik-teknik atau cara tertentu peramalan bukan hanya sekedar taksiran. Semakin baik ramalan tersedia untuk pimpinan semakin baik pula prestasi kerja mereka sehubungan dengan keputusan yang diambil. Ramalan yang dilakukan umumnya akan berdasarkan pada data masa lampau yang dianalisa dengan menggunakan cara-cara tertentu. Data masa lampau dikumpulkan, dipelajari, dan dianalisa dihubungkan dengan perjalanan waktu. Karena adanya faktor waktu itu, maka dari hasil analisa tersebut dapat dikatakan sesuatu yang akan terjadi pada masa mendatang. Teknik peramalan tidak selamanya selalu tepat karena teknik peramalan yang digunakan belum tentu sesuai dengan sifat datanya atau disebabkan oleh kondisi di luar yang mengharuskan peramalan perlu menyesuaikan diri. Oleh karena itu, perlu diadakan pengawasan peramalan sehingga dapat diketahui sesuai atau tidaknya teknik peramalan yang digunakan. Sehingga dapat dipilih dan ditentukan teknik peramalan yang lebih sesuai dengan cara menentukan batas toleransi peramalan atas penyimpangan yang terjadi.

Pada prinsipnya, pengawasan peramalan dilakukan dengan membandingkan hasil peramalan dengan kenyataan yang terjadi. Penggunaan teknik peramalan yang menghasilkan penyimpangan terkecil adalah teknik peramalan yang paling sesuai untuk digunakan.

\subsubsection{Peramalan Data Time Series}

Forecasting atau peramalan adalah mengestimasi nilai masa depan berdasarkan pola-pola didalam sekumpulan data (Turban, 2005). Time Series merupakan teknik peramalan yang mendasarkan pada data masa lalu (data historis) dan dapat dibuat dalam bentuk angka yang biasa disebut sebagai data Time Series (Turban, 2009).

Time Series adalah kumpulan dari pengamatan yang teratur pada sebuah variabel selama periode waktu yang sama dan suksesif. Peramalan dapat diterapkan bila terdapat kondisi seperti tersedianya informasi data historis, informasi tersebut dapat dikuantitatifkan dalam bentuk numeric dan dapat diasumsikan bahwa beberapa aspek pola masa lalu akan terus berlanjut diwaktu mendatang. 


\subsubsection{Exponential Smoothing}

Exponential Smoothing adalah suatu tipe teknik peramalan rata-rata bergerak yang melakukan pertimbangan terhadap data masa lalu dengan cara eksponential sehingga data paling akhir mempunyai bobot atau timbangan lebih besar dalam rata-rata bergerak (Murray R. Spiegel, Ph.D 2007).

Rumus umum metode Single Exponential Smoothing adalah sebagai berikut (Murray R. Spiegel, Ph.D 2007) :

$$
\left(S_{t+1}=a X_{t}+(1-a) S_{t}\right)
$$

Keterangan :

$X_{\mathbf{t}}$ : data asli pada periode ke-t

$S_{t} \quad$ : nilai peramalan pada periode ke-t

$\mathrm{t}+1$ : periode peramalan (waktu hendak dilakukan peramalan)

a : nilai perkiraan fluktuasi (diisi nilai antara $0 \mathrm{~s} / \mathrm{d} 1$ )

\subsection{Least Square}

Least Square adalah metode peramalan yang digunakan untuk melihat trend dari data deret waktu (Hendra Kusuma, 2009). Rumus umum metode Least Square: $\mathbf{Y}=\mathbf{a}+\mathbf{b x}$

Keterangan :

Y : Jumlah penumpang di halte

a : Konstanta

b : Koefisien regresi

$x$ : Waktu atau periode penelitian

$\mathrm{n}$ : Jumlah sample data

$\mathrm{t}$ atau koding: skala absolut

Cara untuk menjabarkan persamaan regresi $\mathbf{Y}=\mathbf{a}+\mathbf{b x}$ adalah menggunakan bantuan nilai $x / t$ yang berarti data setiap waktu tertentu dalam bentuk kode. Dalam menentukan nilai $x / t$ (data untuk setiap waktu tertentu) seringkali digunakan teknik alternatif dengan memberikan skor atau kode. Dalam hal ini dilakukan pembagian data menjadi dua kelompok, yaitu :

- Data genap, maka skor nilai t nya : ..., $-5,-3,-1,1,3,5, \ldots$

- Data ganjil, maka skor nilai t nya : ..., $-3,-2,-1,0,1,2,3, \ldots$

\subsection{MAD (Mean Absolut Devitiation)}

Mean Absolute Deviation adalah nilai absolute dari penyimpangan data terhadap mean. Dengan mengetahui nilai MAD kita bisa mengetahui penyimpangan data dari rata-rata atau tingkat kesalahan peramalan menggunakan rumus sebagai berikut :

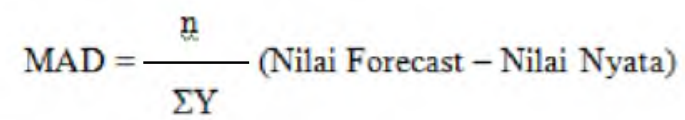




\section{Implementasi dan Analisa}

\subsection{Implementasi Sistem}

Berdasarkan analisis dari desain sistem yang telah dilakukan, maka telah diimplementasikan sebuah sistem peramalan menggunakan metode Exponential Smoothing dan Least Square untuk jumlah penumpang halte bus Trans Jogja. Implementasi sistem ini bertujuan untuk memprediksi jumlah penumpang pada waktu yang akan datang yang nantinya dijadikan pertimbangan untuk pengambilan keputusan. Sistem ini dibangun dengan bahasa pemrograman Delphi 7.0 dan Database PostGreSQL.

Menu perhitungan peramalan dengan Least Square, halaman ini merupakan hasil dari proses perhitungan peramalan dengan metode Least Square dengan menginputkan kode halte, waktu mulai prediksi sampai akhir atau rentan waktu yang akan dihitung. Setelah proses perhitungan maka akan didapat prediksi jumlah penumpang halte bus pada waktu mendatang. Tampilan Menu Peramalan Least Square dapat dilihat pada Gambar 1.

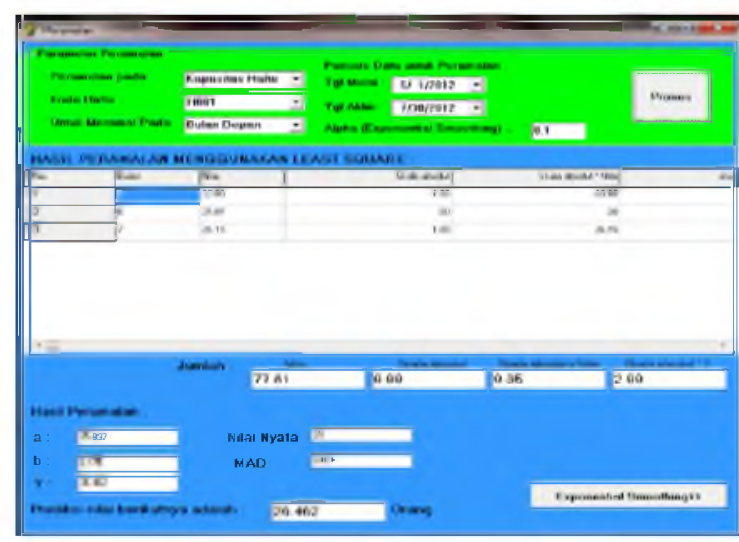

Gambar 1 Tampilan Menu Perhitungan Least Square

Pada form perhitungan Least Square diatas menampilkan proses manual perhitungan metode Least Square dengan memperlihatkan tabel proses perhitungan. Hasil proses peramalan ada pada prediksi nilai berikutnya. Selanjutnya proses perhitungan dilanjutkan dengan menggunakan metode Exponential Smoothing. Halaman ini merupakan kelanjutan dari halaman perhitungan menggunakan Least Square. proses prediksi jumlah penumpang dilakukan dengan metode Exponential Smoothing. selanjutnya hasil dari kedua metode dibandingkan pada menu sistem pendukung keputusan, manakah yang lebih baik dari kedua metode berdasarkan nilai MAD atau nilai eror yang lebih kecil berarti yang lebih baik karena memiliki tingkat eror yang lebih kecil. Tampilan Menu Peramalan Exponential Smoothing dapat dilihat pada Gambar 2. 


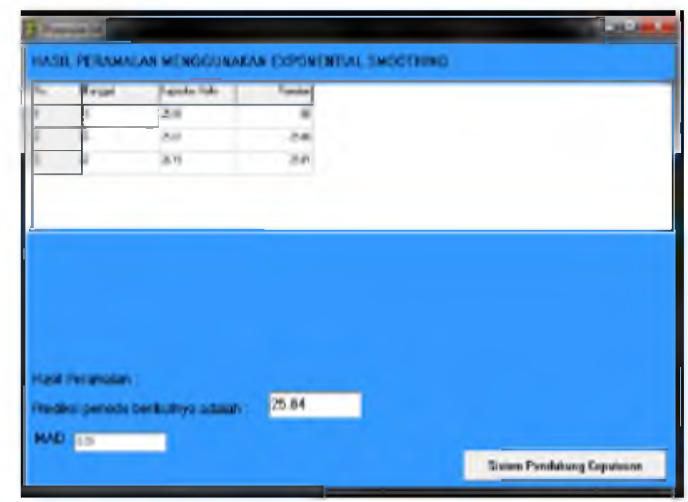

Gambar 2 Tampilan Menu Perhitungan Exponential Smoothing

Implementasi menu sistem pendukung keputusan, Pada halaman ini terdapat hasil perhitungan peramalan jumlah penumpang dari Least Square dan Exponential Smoothing. Jika jumlah penumpang melebihi kapasitas halte maka pada halaman ini akan menampilkan jumlah kekurangan dan harus diperluas berapa meter. Perhitungan dengan metode Exponential Smoothing menggunakan alpha 0,1 dan akan menunjukkan hasil nilai eror dari masing-masing perhitungan. Hasil nilai eror yang lebih kecil akan dipakai untuk pengambilan keputusan. Tampilan Menu Sistem Pendukung Keputusan dapat dilihat pada Gambar 3.

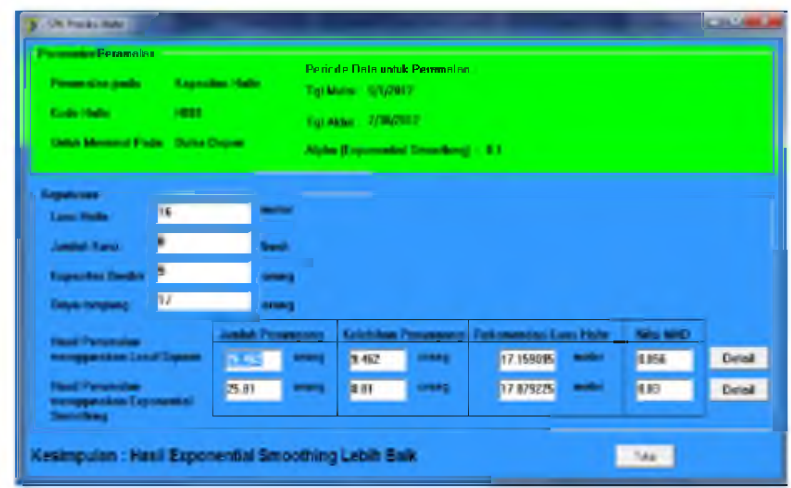

Gambar 3 Tampilan Menu Sistem Pendukung Keputusan

Form Sistem Pendukung Keputusan memperlihatkan hasil rekomendasi ukuran halte yang dapat diberikan kepada manajemen. Ukuran halte yang dipilih adalah ukuran yang diperoleh dari hasil perhitungan yang mengandung nilai MAD terendah.

\subsection{Analisa Hasil}

Sistem yang telah dibuat merupakan penerapan dari metode yang ada, yaitu metode peramalan yang dibuat dalam bentuk sebuah program dengan perhitungan Least Square dan Exponential Smoothing dengan demikian hasil yang didapat tidak jauh berbeda dengan perhitungan manualnya.

\subsubsection{Kapasitas penumpang minimum dalam halte Malioboro I}

* Ukuran tempat duduk untuk 1 orang :

Panjang $=0,6$ meter.

Lebar $=0,6$ meter

* Ukuran berdiri untuk 1 orang adalah 0,1225 meter. 
* Panjang tempat duduk I adalah 4 meter.

Kapasitas tempat duduk I $=4: 0,6=6$ orang.

* Panjang tempat duduk II adalah 1,4 meter.

Kapasitas tempat duduk II $=1,4: 0,6=2$ orang.

*luas area berdiri $=$ panjang halte $\times$ (lebar halte - (lebar tempat duduk I + lebar tempat duduk II))

$=1,4 \times(2-(0,6+0,6))$ meter $=1,12$ meter $^{2}$.

Kapasitas tempat untuk berdiri $=1,12: 0,1225=9$ orang.

Jadi kapasitas total halte Trans Jogja adalah 17 orang.

\subsubsection{Hasil Sistem}

Hasil sistem yang didapatkan harus diuji nilainya dengan membandingkan hasil pengujian sistem secara manual, sehingga dengan perbandingan ini akan didapatkan hasil sistem yang benar-benar sesuai dengan hitungan manualnya dan dapat dibandingkan dengan hasil dari perhitungan aplikasi.

Tahap perhitungan yang diperlukan :

1. Menentukan periode waktu peramalan (waktu yang hendak dilakukan peramalan).

2. Memberikan nilai perkiraan fluktuasi (diisi nilai antara $0 \mathrm{~s} / \mathrm{d} 1$ ) pada perhitungan Exponential Smoothing.

3. Untuk perhitungan Least Square menentukan nilai nilai $\mathrm{x} / \mathrm{t}$ (data untuk setiap waktu tertentu) dengan membagi data menjadi dua kelompok yaitu

- Data genap, maka skor nilai t nya : ..., $-5,-3,-1,1,3,5, \ldots$

- Data ganjil, maka skor nilai t nya : ..., -3, -2, $-1,0,1,2,3, \ldots$

4. Menghitung nilai Mean Absolut Deviation (MAD) atau kesalahan peramalan pada hasil perhitungan Least Square dan Exponential Smoothing.

5. Menentukan nilai MAD paling kecil.

Sebagai contoh, peramalan atau prediksi jumlah penumpang pada halte Malioboro I bus Trans Jogja pada bulan Mei sampai dengan Juli 2012 untuk peramalan jumlah penumpang pada bulan berikutnya yaitu bulan Agustus 2012.

Langkah-langkah perhitungannya sebagai berikut :

1. Menentukan periode waktu peramalan.

Periode waktu peramalan dilakukan berdasarkan lama atau waktu survei di lapangan. Dari permasalahan diatas periode peramalan mulai dari bulan Mei sampai dengan Juli 2012 untuk peramalan jumlah penumpang pada bulan Agustus 2012.

2. Memberikan nilai a (alpha) pada perhitungan Exponential Smoothing (a $0 \mathrm{~s} / \mathrm{d} 1$ ).

3. Rumus Exponential Smoothing berdasarkan persamaan 2.2 yang dituliskan kembali sebagai berikut.

$$
\left(S_{t+1}=a X_{t}+(1-a) S_{t}\right)
$$




\begin{tabular}{|c|c|c|c|c|}
\hline No & Bular & $\begin{array}{c}\text { Jumlah } \\
\text { penumpang }(\mathrm{Xt})\end{array}$ & $\begin{array}{l}\text { Exponential Smoothing } \\
\left(S_{t+1}=\alpha X_{t}+(1-a) S_{t}\right)\end{array}$ & $S t$ \\
\hline 1 & 1 & 25,80 & 0.00 & \\
\hline 2 & 2 & $25: 87$ & $\begin{aligned} \mathrm{S}_{2+1} & =(0.1(25.87)+(1-0.1) \times 25,80) \\
S_{3} & =2,587+(0.5 \times 25,8) \\
S_{3} & =2,587+23.22=25,80\end{aligned}$ & 25,80 \\
\hline 3 & 3 & 26.15 & $\begin{aligned} S_{1-1} & =(0.1(25,15)+(1-0.1) \times 25,80) \\
s_{4} & =2,515+(0.9 \times 25,80) \\
s_{4} & =2,515+23.22=25,81\end{aligned}$ & 2584 \\
\hline
\end{tabular}

Jadi, hasil perhitungan Exponential Smoothing untuk peramalan jumlah penumpang bulan ke-4 atau bulan Agustus adalah 25,84 orang.

Kapasitas total halte Trans Jogja berdasarkan ukuran halte, satuan luas dan ruang gerak penumpang di dalam halte adalah 17 orang. Untuk kelebihan jumlah penumpang sejumlah 9,46 orang diasumsikan pada ruang berdiri. Dari ukuran halte yang ada perlu di perlebar ukurannya menjadi :

Ukuran berdiri untuk 1 orang : 0,1225 meter.

Jadi ukuran halte yang perlu ditambah untuk 9,46 orang penumpang adalah

$9,46 \times 0,1225=1,15885$ meter. Dari ukuran semula yang 16 meter menjadi 17,1590 meter $^{2}$.

Sedangkan, untuk mengetahui tingkat kesalahan peramalan atau standar eror menggunakan rumus sebagai berikut :

$$
\begin{aligned}
& \text { MAD }=\frac{\mathrm{n}}{\Sigma \mathrm{Y}} \text { (Nilai Forecast }- \text { Nilai Nyata) } \\
= & ---(25,84-25) \\
78,81 & \\
= & 0,03
\end{aligned}
$$

4. Untuk perhitungan Least Square menentukan nilai nilai $\mathrm{x} / \mathrm{t}$ (data untuk setiap waktu tertentu)

Dengan $N=3$ bulan

- Data genap, maka skor nilai t nya : ..., $-5,-3,-1,1,3,5, \ldots$

Berdasarkan persamaan 2.2 yang dituliskan kembali sebagai berikut.

$$
\mathbf{Y}=\mathbf{a}+\mathbf{b x}
$$

Selanjutnya untuk mengetahui koefisien a dan b di cari dengan menggunakan rumus :

$$
\mathrm{a}=\frac{\Sigma \mathrm{Y}}{\mathrm{n}} \quad \mathrm{dan} \quad \mathrm{b}=\frac{\Sigma \mathrm{t} \mathrm{Y}}{\Sigma \mathrm{t}^{2}}
$$




\begin{tabular}{|c|c|c|c|c|c|}
\hline Mo & Bulan ke- & $\begin{array}{c}\text { Jumlah Penumpang } \\
\mathrm{Y}\end{array}$ & $\begin{array}{c}\text { Koding } \\
(\mathrm{t})\end{array}$ & $(\mathrm{TW})$ & $\left(\mathrm{i}^{2}\right)$ \\
\hline 1 & 1 & 25,80 & -1 & -2580 & 1 \\
\hline 2 & 2 & 25,87 & 0 & 0 & 0 \\
\hline 3 & 3 & 25,15 & 1 & 26,15 & 1 \\
\hline & Jumlah Total & 77,81 & 0 & 0,35 & 2 \\
\hline
\end{tabular}

77,81

$$
\mathrm{a}=-\frac{-}{3}=25,937
$$

$$
\mathrm{b}=-\frac{0,35}{2}--=0,175
$$

$\mathrm{Y}=\mathrm{a}+\mathrm{bx}$

$=25,937+(0,175) 3$

$=25,937+0,525$

$=26,462$

Jadi, hasil perhitungan Least Square untuk peramalan jumlah penumpang bulan ke-4 atau bulan Agustus adalah 26,462 orang.

Kapasitas total halte Trans Jogja berdasarkan ukuran halte, satuan luas dan ruang gerak penumpang di dalam halte adalah 17 orang. Untuk kelebihan jumlah penumpang sejumlah 9,462 orang diasumsikan pada ruang berdiri. Dari ukuran halte yang ada perlu di perlebar ukurannya menjadi :

Ukuran berdiri untuk 1 orang : 0,1225 meter.

Jadi ukuran halte yang perlu ditambah untuk 9,462 orang penumpang adalah $9,462 \times 0,1225=1,1590$ meter $^{2}$. Dari ukuran semula yang 16 meter menjadi 17,159 meter ${ }^{2}$.

Sedangkan, untuk mengetahui tingkat kesalahan peramalan atau standar eror menggunakan rumus sebagai berikut :

$$
\mathrm{MAD}=\frac{\mathrm{n}}{\Sigma \mathrm{Y}}(\text { Nilai Forecast }- \text { Nilai Nyata })
$$

$$
\begin{aligned}
& =\frac{3}{78,31}-(26,465-25) \\
= & 0,056
\end{aligned}
$$

Jadi dari hasil perhitungan menggunakan Exponential Smoothing dan Least Square diperoleh kesimpulan yang dapat dilihat pada Tabel 4.6. 
Tabel 4.6 Perhitungan Exponential Smoothing dan Least Square

\begin{tabular}{|c|c|c|}
\hline Hasil Peranalan & Exponentiol Swoothing & Least Syure \\
\hline Tumlah Penumpang & 25,84 arang & 26.462 oxang \\
\hline Kelebihan Penumpang & 884 orang & 9,462 orang \\
\hline Rekomendasis Luas halte & 170889 meter & $17.1500 \mathrm{met}^{2}$ \\
\hline Niai MAD & 0.03 & 0,056 \\
\hline
\end{tabular}

Kerena nilai Mean Absolut Deviation (MAD) atau kesalahan peramalan pada Exponential Smoothing lebih kecil dengan demikian, peramalan untuk jumlah penumpang bulan berikutnya lebih baik menggunakan perhitungan Exponential Smoothing.

\section{Kesimpulan}

Kesimpulan dari penelitian skripsi dengan judul, Sistem Pendukung Keputusan Prediksi Jumlah Penumpang Untuk Evaluasi Kapasitas Halte Bus Trans Jogja Dengan Metode Exponential Smoothing Dan Least Square adalah :

1. Pada hasil uji coba dapat diketahui bahwa terjadi kenaikan jumlah penumpang, sehingga Halte Malioboro I perlu diperluas ukuranya.

2. Rekomendasi luas halte dapat diketahui dengan membandingkan selisih antara jumlah penumpang hasil peramalan dengan kaspasitas halte.

3. Diantara kedua metode yaitu Exponential Smoothing dan Least Square yang lebih baik digunakan adalah metode peramalan dengan menggunakan Exponential Smoothing karena menghasilkan nilai MAD yang lebih kecil.

\section{Daftar Pustaka}

Andi, dan Wahana, 2000 Tips dan Trik Pemrograman Delphi 7.0 edisi : 1. Wahana dan Andi, Yogyakarta.

Adiyasa, Yoga, 2011, Penggunaan Model SimulasiUntuk Evaluasi Waktu Tunggu Penumpang Dan Kapasitas Halte Trans Jogja. Tesis tidak diterbitkan. Yogyakarta : Jurusan Teknik dan Sistem Transportasi UGM Yogyakarta.

Hadi, Sutrisno, MA, 2002, Statistik Jilid 3, CV. Andi Offset, Yogyakarta.

Kusuma, Hendra, 2009, Perencanaan Dan Pengendalian Produksi. CV. Andi Offset, Yogyakarta.

Nugroho, Adi, 2011, Perancangan Dan Implementasi Sistem Basis Data. CV.Andi Offset, Yogyakarta.

Putra, Dwi Rendra. 2009. Penyusunan Model Fasilitas Halte Bus Trans Jogja. Skripsi tidak diterbitkan. Yogyakarta : Jurusan Teknik Sipil dan Lingkungan UGM Yogyakarta.

R.Spiegel, Murray, Ph.D dan Stephens, Larry J, Ph.D, 2007, Schaums Outlines Teori dan SoalSoal Statistik Edisi ke-3. Erlangga, Jakarta.

Sunyoto, Danang, SE., SH., MM, 2011, Analisis Regresi Dan Uji Hipotesis. CAPS, Yogyakarta. 
Turban, Efram, Aronson, Jay E, dan Peng-Liang, Ting, 2005, Decision Support System and Intelligent Systems (Sistem Pendukung Keputusan dan Sistem Cerdas). CV. Andi Offset, Yogyakarta. 